\title{
Trade, the Precautionary Principle, and Post-Modern Regulatory Process
}

\author{
Regulatory Convergence in the Transatlantic Trade and Investment \\ Partnership*
}

Lucas Bergkamp and Lawrence Kogan**

\section{Introduction}

The Transatlantic Trade and Investment Partnership ("TTIP") has been hailed as an opportunity for the world's two largest consumer markets to expand inter-regional trade, investment and jobs, and to secure greater regulatory convergence that could considerably reduce costly and market-distorting extra-territorial non-tariff regulatory trade barriers. ${ }^{1}$ As fears of potential adverse effects on the World Trade Organization's multilateral trading system have abated after the Doha round stalled, ${ }^{2}$ the initiation of the TTIP has been welcomed by the business communities on both sides of the Atlantic. ${ }^{3}$

Notwithstanding the anticipated benefits, questions arise with respect to both the way the negotiations are conducted and the topics covered. The TTIP negotiating mandate covers three main elements: (i) market access, (ii) regulatory convergence, and (iii) trade rules addressing shared global challenges. Of the three, regulatory convergence offers by far the greatest potential for substantial and lasting benefits. Regulatory convergence could potentially be achieved through presumptive mutual recognition, ${ }^{4}$ voluntary unilateral recognition of equivalence, ${ }^{5}$ voluntary asymmetric recognition, ${ }^{6}$ some form of regulatory cooperation, ${ }^{7}$ or a combination of these approaches. As the Commission acknowledges, “[i]n today's transatlantic trade relationship, the most significant trade barrier is not the tariff paid at the customs, but socalled 'behind-the-border' obstacles to trade, such as different safety or environmental standards for cars. $^{\prime 8}$ The plan is to negotiate ambitious agreements on sanitary and phyto-sanitary (SPS-plus) and technical barriers to trade (TBT-plus) measures, regulatory compatibility in specific sectors, such as chemical, automotive, ICT, and pharmaceutical (to be specified in annexes to the agreement), the so-called 'cross-cutting' disciplines, and an institutional framework for regulatory cooperation going forward.

This opportunity notwithstanding, Europe's precautionary principle ("PP") has been identified as a

* The authors wish to thank Prof. Alberto Alemanno, HEC Paris and New York University, who provided very helpful comments on an earlier draft of this article. Any errors or omissions remain the sole responsibility of the authors.

** Dr Lucas Bergkamp, Hunton \& Williams, Brussels; Lawrence A. Kogan, The Kogan Law Group, P.C., New York.

1 Transatlantic Economic Council High Level Working Group on Jobs and Growth, "Final Report", 11 February 2013, at p. 1; The White House, Office of the Press Secretary, "U.S., EU Announce Decision to Launch Negotiations on a Transatlantic Trade and Investment Partnership", 13 February 2013

2 To the contrary, the Commission now opines that "the TTIP could end up encouraging others to revive the WTO negotiations." European Commission, "TTIP Questions and Answers", available at <http://ec.europa.eu/trade/policy/in-focus/ttip/questions-andanswers/> (last accessed on 26 November 2013). On the other hand, Lamy has noted that, while "[a]greeing to regulatory standards at a bilateral or regional level could lead to deeper regional integration, it could also complicate the process of achieving a much more global agreement with 'regulatory coherence' and potentially raise new barriers to trade." Shawn Donnan, "Pascal Lamy Questions US-led Regional Trade Talks", 18 July 2013, Financial Times.

3 BusinessEurope, "Massive Scope for EU-US Trade Agreement to Drive Growth and Jobs Creation Across Europe", Press Release of 14 June 2013. National Association of Manufacturers, "Public Comments Concerning the Proposed Transatlantic Trade and Investment Partnership", 10 May 2013. Business Coalition for Transatlantic Trade, "BCTT Working Group Recommendations Concerning the Transatlantic Trade and Investment Partnership", July 2013.

4 Luigi Russi, "Economic Analysis of Article 28 EC after the Keck Judgment", 7 German Law Review (2005), 479 et sqq, at p. 483.

5 Organization for Economic Cooperation and Development, "Trade and Regulatory Reform: Insights from Country Experience", 2001, at p. 101.

6 This approach engenders an importing State's unilateral decision whether or not voluntary, to recognize the standards and regulations of a more stringent regulatory system that generally meets its public policy objectives in order to avoid the costs, burdens and resources needed to establish its own measures.

7 European Commission, "Transatlantic Trade and Investment Partnership: The Regulatory Part", September 2013.

8 DG Trade, <http://trade.ec.europa.eu/doclib/press/index.cfm?id=918> (last accessed on 26 November 2013). 
potential obstacle to a successful TTIP outcome. ${ }^{9}$ On the one hand, the European Parliament has called for the TTIP not to undermine fundamental EU cultural values such as the $\mathrm{PP}^{10}$ and regulations concerning genetically-modified organisms (GMOs), cloning, intellectual property rights, and the EU's geographical indication of origin system. ${ }^{11}$ Friends-of-theEarth $^{12}$ and EU Green Parties ${ }^{13}$ have argued that the WTO Agreements' strict scientific risk assessment and economic cost-benefit analysis requirements could undermine PP implementation for human health and environmental regulatory purposes. On the other hand, BusinessEurope, ${ }^{14}$ the National Association of Manufacturers, ${ }^{15}$ and the National Association of State Departments of Agriculture ${ }^{16}$ have urged that TTIP-regulatory frameworks not be premised on a hazard-based PP, which may lead to regulatory outcomes that are inconsistent with science, and risk assessment and cost-benefit principles. ${ }^{17}$ The arguments proffered by both sides, however, are generally not based on empirical research. It remains unclear, for instance, whether, and, if so, in which cases, a TTIP that sets forth a process for allowing the marketing in the EU of products complying with US regulations would have the potential to cause any adverse effects on consumer protection, human health, or the environment.

Following a brief discussion of transparency in the TTIP negotiations, this article turns to the key topic

9 Maine Government, "TTIP FAQ - Negotiation Phase (Transatlantic Trade and Investment Partnership)", 12 July 2013, at p. 4.

10 European Parliament Resolution of 23 May 2013 on EU Trade and Investment Negotiations with the United States of America, (2013/2558(RSP)), at par. 17.

11 "Euro-MPs Back US Trade Talks, But With 'Cultural' Exceptions", EU Business, 24 May 24 2013, available at <http://www.eubusiness.com/news-eu/us-trade-france.oqa> (last accessed on 26 November 2013).

12 Magda Stoczkiewicz, "Trading Away Citizen and Environmental Safeguards", European Voice, 10 October 2013.

13 EU Green Party, Draft Resolution to be Voted on - Transatlantic Trade and Investment Partnership (TTIP), at p. 2,

14 BusinessEurope, "Correspondence to Members and Substitutes of the Internal Market \& Consumer Protection Committee (IMCO)", 24 September 2013, at p. 2.

15 National Association of Manufacturers, "Public Comments Concerning the Proposed Transatlantic Trade and Investment Partnership", 10 May 2013, at p. 2 ("[m]anufacturers strongly urge that regulatory frameworks and outcomes not be based on the EU's so-called Precautionary Principle, which leads to regulatory outcomes that are contrary to basic science, risk assessment and cost-benefit principles.").

16 NASDA, "Letter to Deputy National Security Advisor Mike Froman on TTIP", May 2013, at p. 1. ("At the core, the EU's nonscientific notion of 'precaution' has led to the adoption of many of regulatory convergence. In our view, the TTIP presents a significant opportunity for creating a process for regulatory cooperation, harmonization, and convergence. ${ }^{18}$ As the title suggests, we focus on the PP and related differences in regulatory procedures. Specifically, we discuss the PP's relation to post-modernism, and its influence on EU regulatory procedure and science, highlighting the paradoxes inherent in the PP. To put these issues into perspective, we also review the 'reality of precaution.' In light of this analysis, we assess the effectiveness of the trading partners' attempts to reduce the regulatory divide, and explore what the trading partners can learn from each other. We then proceed to present some recommendations on how they should proceed in the TTIP negotiations.

\section{Transparency in the TTIP Negotiations}

To their credit, the European Commission and the Office of the United States Trade Representative ("USTR") have, thus far, been more transparent than during prior trade negotiations. For example, the information they have provided about the negotiating mandate and the status of the discussions, ${ }^{19}$ at least, enables stakeholders to see the 'big picture' and to prognosticate about potentially successful outcomes;

trade-restrictive measures that have resulted in several highprofile WTO disputes in which the EU's defense of the precau tionary principle has been ruled to be inconsistent with WTO rules. Such precautionary measures are often based on mere hazard identification - or worse, on public perception and political considerations - rather than proper, science-based risk assessments, as required by the WTO. And, even in cases where risk assessments are ultimately carried out, the EU has demonstrated an inability to lift unjustifiable measures because of domestic political pressures. 'Precaution' in the EU has become a pretext for import protectionism under the pretense of consumer safety. As a result, U.S. exports have repeatedly paid the price.").

17 The Business Coalition for Transatlantic Trade ("BCTT") developed a set of recommendations for the TTIP negotiating Parties' use which emphasized that "[s]cience-based decision making and not the precautionary principle must be the defining principle in setting up mechanisms and systems that will address both today's SPS barriers and those of the future." Business Coalition for Transatlantic Trade, BCTT Working Group Recommendations Concerning the Transatlantic Trade and Investment Partnership, July 2013, at p. 10.

18 Regulatory harmonization and regulatory compatibility are flip sides of the same coin. Regulatory convergence is the rate at which harmonization is achieved. Regulatory cooperation is a process aimed at achieving convergence.

19 DG Trade's website is the EU's primary source of information: $<$ http://ec.europa.eu/trade/policy/in-focus/ttip/> (last accessed on 26 November 2013). The USTR's TTIP website can be found at <http://www.ustr.gov/ttip> (last accessed on 26 November 2013). 
but, candidly, there remains a lot to be desired of the less than robust level of transparency on display.

On the one hand, the European Commission claims to be "very responsive to the need to make the negotiating process as transparent as possible for $\mathrm{Eu}$ ropean citizens. ${ }^{20}$ On the other hand, it justifies the decision to keep the DG Trade negotiating mandate confidential on the need "to keep chances for a satisfactory outcome high." ${ }^{21}$ In a related Factsheet, the Commission adds that "[a] certain level of confidentiality is necessary to protect EU interests" and that "[n]egotiators have to trust each other to come to a deal that satisfies both sides." 22 Yet, it is difficult to see how the all but 'closed' negotiations can produce the desired climate of confidence that would enable negotiators on both sides to work together to come to the best deal possible, especially in the absence of public scrutiny and, possibly, public confidence.

Of course, there is much historical precedent for keeping the doors to trade negotiation rooms closed; but is this still sound strategy today in an era of the ubiquitous internet and Wikileaks? ${ }^{23}$ Perhaps, the negotiating parties' less-than-transparent negotiating posture was inspired by the early success of the European Community's 'integration by stealth'? ${ }^{24}$ Clearly, they seem to have been unmoved by either the Lisbon Treaty's promise of greater transparency ${ }^{25}$ or the prior failure of ACTA negotiations for reason of insufficient transparency and negative public scrutiny. ${ }^{26}$

The desire to negotiate in secrecy may be understandable, but it may also involve a risk of backfir-

20 European Commission, "Member States Endorse EU-US Trade and Investment Negotiations", MEMO/13/564, Brussels, 15 June 2013.

21 Ibid.

22 European Commission, "Factsheet on Transparency in Trade Negotiations", June 2013, at p. 4. It is the Commission's view that the public disclosure of its negotiating position would reveal "its entire strategy to [its] counterpart", and thus, jeopardize its ability to "meet the objectives set out in the instructions from the Council." Ibid.

23 Alex Hern and Dominic Rushe, "WikiLeaks Publishes Secret Draft Chapter of Trans-Pacific Partnership", The Guardian, 13 November 2013.

24 Giandomenico Majone, Dilemmas of European Integration: The Ambiguities and Pitfalls of Integration by Stealth (Oxford: Oxford University Press, 2005); Christian Engström, "EU Commissioner De Gucht Says No to Transparent TTIP Negotiations", Christian Engström, Pirate MEP Blog, 23 May 2013

25 Juan Mayoral, "Democratic Improvements in the European Union Under the Lisbon Treaty: Institutional Changes Regarding Democratic Government in the EU", European University Institute European Union Democracy Observatory, February 2011, pp. 7-8.

26 "Will the EU Parliament Let TAFTA Turn Into Another ACTA?", 24 April 2013, Infojustice.org; Michael Carbone, "With ACTA Lessons Unlearned, An Uncertain Future for '21st Century' Free Trade Agreements", Bertelsmann Stiftung Future Challenges, 25 April 2013. ing, either during the process or at the end. To no great surprise, the limited transparency of the process has already given rise to protests by consumer organizations ${ }^{27}$ and legislators. ${ }^{28}$ Indeed, the public is unable to ascertain exactly what is being discussed, and whether the key issues requiring an agreement are being addressed. Even if not all negotiation sessions are opened up to public attendance, the updates provided by the negotiators are not helpful.

Although it is difficult to ascertain exactly what is on the table due to the lack of transparency, the limited public statements released by the two blocks suggest that they have adopted a strategy to work around some of the most sensitive regulatory issues in the transatlantic relations. To appease environmental and consumer organizations, both US and EU officials have been outspoken on one specific issue: the precautionary principle ('PP') and the associated differences in regulatory process. USTR Michael Froman attempted to downplay the debate over Europe's PP preference and America's economic cost-benefit analysis focus, calling it a "caricature" and "largely anachronistic." ${ }^{29}$ Even more bluntly, EU Trade Commissioner Karel De Gucht ${ }^{30}$ and EU Consumer Policy Commissioner, Neven Mimica ${ }^{31}$ have remarked in separate public settings that they would not compromise on the PP in TTIP negotiations. Is the debate over the PP and the related differences in regulatory procedures really anachronistic, or does Froman intend to suggest that the US is ready to endorse the PP or parts of it? Legally, the European Commission-

27 Corporate Europe Observatory, "Busting the Myths of Transparency Around the EU-US Trade Deal", 25 September 2013; TransAtlantic Consumer Dialogue, "TACD Stakeholder Forum: The Transatlantic Trade and Investment Partnership: Can it Bring Benefits to the People?", Summary Report, 29 October 2013, at pp. 2 and 4; Glyn Moody, "ISDS: ACTA by the Back Door?", ComputerWorldUK, 17 October 2013.

28 DeLauro, "Miller Lead 151 House Dems Telling President They Will Not Support Outdated Fast Track For Trans-Pacific Partnership", Congresswoman Rosa DeLauro Press Release, 13 November 2013; Tea Party, "Progressives Unite on Fast-Track Trade Authority", Washington Times Communities, 13 November 2013; Paul Sracic, "The Odd Bipartisan Coalition That Could Sink Obama's Free-Trade Legacy", The Atlantic, 18 June 2013.

29 Office of the United States Trade Representative, "Remarks by U.S. Trade Representative Michael Froman on the United States, the European Union, and the Transatlantic Trade and Investment Partnership", 30 September 2013.

30 Karel De Gucht, "Speech - Transatlantic Trade and Investment Partnership (TTIP) - Solving the Regulatory Puzzle", Europa Press Release (SPEECH/13/801), 10 October 2013.

31 Steve Suppan, "The Struggle for Transparency in the U.S.-EU Trade Deal", Institute for Agriculture and Trade Policy Blog, 5 November 2013 (describing comments made by Neven Mimica regarding the $\mathrm{PP})$. 
ers cannot 'negotiate away' the PP, which is enshrined in the EU's constitutional documents; ${ }^{32}$ but could they not, at least, enter into agreements that would neutralize some of its adverse effects?

Maybe that is what the parties intend to do, but there is no way of knowing. Indeed, it is conceivable that these public statements are merely political posturing and that PP-related issues in fact feature high on the agenda. Maybe the trade negotiators concluded that the TTIP provides an excellent opportunity to create a transatlantic framework for rational regulatory process that incorporates some elements of EU-style decision making under conditions of uncertainty and counteracts the overly cautious elements.

\section{Regulatory Cooperation, Harmonization, and Convergence}

The Commission estimates that the reduction of regulatory trade barriers would account for approximately two thirds of the total economic benefits resulting from a successful TTIP. ${ }^{33}$ Thus, the parties feel obliged, in their fiduciary capacity, to resolve major inconsistencies in regulatory philosophy that could deny their citizens such large benefits. A frank debate on the PP, of course, is essential to any such resolution. If the political preference for employing a stealth approach to TTIP negotiations indeed serves the purpose of advancing regulatory cooperation, harmonization, and convergence in this manner, the EU and US may be forgiven for not being more transparent. On the other hand, regulatory cooperation, harmonization, and convergence will be less effective if the parties fail to deal with the PP and its consequences. No doubt, these discussions may be tough and clever drafting will be required to avoid subsequent challenges, as the regional differences in regulatory science and related decision-making procedures are among the most publicly controversial nontariff trade barriers ("NTBs"). But the prize is worth the effort, as harmonizing or aligning regulatory procedures is an effective way to prevent future NTBs.

The transatlantic regulatory divide, which has increased with the number of product-related regulations mushrooming in both regions, has resulted in diverging regulations and standards, duplicative testing requirements, diverging conformity procedures, different documentation requirements, corresponding delays, and substantial additional cost. ${ }^{34}$ One of the main objectives of the EU-US trade deal is to reduce 'unnecessary' costs for companies, 'while maintaining high levels of health, safety, consumer and environmental protection.' This requires not only the elimination or reduction of existing NTBs, but also the prevention of new ones. Whether a nontariff regulatory measure rises to the level of an 'unnecessary' non-tariff barrier to trade, however, is likely to become a source of controversy. ${ }^{35}$ Resolving the lingering issues surrounding the PP and the related regulatory differences will go a long way toward addressing existing and preventing future NTBs.

There are several reasons why the EU and US would benefit from tackling the PP-related problems. First, the regulatory processes of both the EU and US demand scientific studies and risk assessments that cater to the needs of regulatory decision makers. For the EU and US to be able to use a common pool of peer-reviewed scientific studies and risk assessments, a common framework guaranteeing data quality is required. Second, the EU's repeated unpredictable use of the PP has prevented the parties from realizing some of the benefits that increased transatlantic trade would otherwise bring. In some cases, arguably, the PP's use has also been non-transparent; a May 2013 Commission regulation on neonicotinoids, ${ }^{36}$ for example, does

32 Note, however, that Article 191(2),TFEU (ex Article 174 TEC) merely declares that the EU's environmental policy "shall be based on the precautionary principle."

33 European Commission, "The Transatlantic Trade and Investment Partnership: The Regulatory Part", September 2013, at p. 2. Cf. European Commission, "Trade, Growth and World Affairs: Trade Policy as a Core Component of the EU's 2020 Strategy", 2010, p. 21. European Commission, "Transatlantic Trade and Investment Partnership: The Economic Analysis Explained", September 2013.

34 For a quantitative assessment, see Centre for Economic Policy Research, "Reducing Transatlantic Barriers to Trade and Investment: An Economic Assessment", Final Project Report, Brussels, March 2013, pp. 15-20.

35 Lawrence A. Kogan, "REACH and International Trade Law", in Lucas Bergkamp (ed.), The European Union REACH Regulation for Chemicals: Law and Practice (Oxford: Oxford University Press, 2013), pp. 309-334.

36 Commission Implementing Regulation (EU) No 485/2013 of 24 May 2013 amending Implementing Regulation (EU) No 540/2011, as regards the conditions of approval of the active substances clothianidin, thiamethoxam and imidacloprid, and prohibiting the use and sale of seeds treated with plant protection products containing those active substances, OJ L 139/12 (25.5.2013). Since Member State voting did not result in a qualified majority, the Commission was to decide whether to adopt the proposed regulation. Its decision to do so was based, in substantial part, on 'data gaps' as regards long term risk to honey bees and the absence of a regulatory impact assessment. For an analysis, see Alberto Alemanno, "The Science, Law and Policy of Neonicotinoids and Bees: A New Test Case for the Precautionary Principle" 4(2) European Journal of Risk Regulation (2013), pp. 191-208. 
not even reference the $\mathrm{PP}$, although it is clearly based on a precautionary approach. ${ }^{37}$ Third, ill-understood and unresolved differences in regulatory procedure will hamper regulatory cooperation to prevent future trade barriers and preclude the realization of gains from "TBT plus" and "enhance[d] regulatory compatibility". ${ }^{38}$ Fourth, there are lessons the trading blocs can learn from each other, such as in relation to addressing uncertainty and stakeholder participation at various stages of the regulatory process. Fifth, since EU product-related standards often find their way into the regulations of other nations, ${ }^{39}$ the US has a strong interest in monitoring and shaping the EU regulatory process. To the extent the EU produces suboptimal regulatory standards, the US and other nations will suffer the consequences. Sixth, the EU's precautionary principle and post-modern regulatory process could also take hold in the US and start to influence legal standards and processes in ways not contemplated by national constitutional and statutory design. ${ }^{40}$

37 It has been suggested that a distinction should be made between the PP and the precautionary approach; the latter would be the Rio Declaration's 'triple negative' statement. We make no such distinction here.

38 European Commission. EU and US Conclude Second Round of TTIP Negotiations in Brussels Press Release (Nov. 15 2013)

39 Anju Bradford, "The Brussels Effect", 107 Northwestern University Law Review (2012), pp. 1-68. For a discussion of the REACH Regulation's impact in the rest of the world, see Daniel Uyesato et al., "REACH's Impact in the Rest of the World", in Lucas Bergkamp (ed.), The European Union REACH Regulation for Chemicals: Law and Practice (Oxford: Oxford University Press, 2013), pp. 335-370.

40 Jeb Rubenfeld, "Two World Orders", Wilson Quarterly, Autumn 2003, p. 26.

41 Industrial Union Department, AFL-CIO v. American Petroleum Institute, 448 U.S. 607, 639 (1980) (wherein the Supreme Court had decided that benzene could be regulated only if it posed a "significant risk of material health impairment"); Joseph C. Morelli, "The Benzene Case: Life, Liberty, and the Pursuit of Health Industrial Union Department, AFLCIO v. American Petroleum Institute", 3 W. New Eng. L. Rev (1980), p. 311 et sqq (discussing how the US Supreme Court "set up a two-part test for carcinogen regulation cases. The first prong... requires the Secretary to demonstrate the existence of a significant risk to employee health. The second prong deals with the existence of a cost-benefit test.").

42 Executive Order 12866, "Regulatory Planning and Review", 58 FR 51735, 4 October 1993; Circular No. A-4, "Regulatory Analysis", Office of Management and Budget, 17 September 2003, (providing "guidance to Federal agencies on the development of regulatory analysis as required under Section 6(a)(3)(c) of Executive Order 12866 "Regulatory Planning and Review," and also providing "guidance to agencies on the regulatory accounting statements that are required under the Regulatory Right-to-Know Act."); Executive Order 13563, "Improving Regulation and Regulatory Review", 76 FR 3821, 21 January

\section{Differences in EU-US Regulatory Process}

The EU and US regulatory procedures evolved in very different ways. In the US, there is Supreme Court precedent requiring federal regulatory agencies to provide strong and reliable scientific evidence and to undertake economic cost-benefit analysis, ${ }^{41}$ which has helped to ensure America's economic and technological advancement and competitiveness during the past several decades. It is feared that the PP might hasten the reestablishment of the high cost regulatory state characteristic of the 1970's that the EU now embraces.

The US built its regulatory process on science-based risk assessment, cost-benefit analysis, and cost-effectiveness analysis. ${ }^{42}$ Admittedly, these regulatory tools are helpful but imprecise and require the exercise of prudent judgment. ${ }^{43}$ In general, statutes stipulate the general requirements or objectives that products must meet (for example, "the public should be protected against unreasonable risks of injury associated with consumer products ${ }^{\prime \prime 4}$ ) and authorize regulatory agen-

2011; Executive Order 13497, "Revocation of Certain Executive Orders Concerning Regulatory Planning and Review", 74 FR 6113, 4 February 2009; White House, "Regulatory Impact Analysis: A Primer" ("providing a primer to assist agencies in developing regulatory impact analyses (RIAs), as required for economically significant rules by Executive Order 13563 , Executive Order 12866, and OMB Circular A-4."). Cf. Ragnar Löfstedt and David Vogel, "The Changing Character of Regulation: A Comparison of Europe and the United States", 21(3) Risk Analysis (2001), pp. 399-405 (presenting the 'flip-flop' theory).

43 Fred Anderson, Mary Ann Chirba-Martin, E. Donald Elliott, Cynthia Farina, Ernest Gellhorn, John D. Graham, C. Boyden Gray, Jeffrey Holmstead, Ronald M. Levin, Lars Noah, Katherine Ryne, and Jonathan Baert Wiener, "Regulatory Improvement Legislation: Risk Assessment, Cost-Benefit Analysis, and Judicial Review", 11 Duke Environmental Law \& Policy Forum (2000), 89 et sqq, at p. 90-91 (discussing how "[r]egulatory agencies use a variety of analytic tools, including comparative risk assessment, cost-benefit analysis, and cost-effectiveness analysis, to inform their decisions and provide a degree of credibility to the decisions that are made," and [h] ow the 103rd, 104th, 105th and 106th Congresses demonstrated sustained interest in the passage of comprehensive legislation governing the employment of (...) analytic tools such as risk assessment and costbenefit analysis to improve the regulatory process" with respect to "public health, safety, and environmental problems".). "Despite differences in terminology, it is well accepted that tools such as risk assessment and cost-benefit analysis offer insight and intellectual discipline to the decision-making process. They can help to identify and evaluate decision options, and achieve more benefits at less cost than otherwise would occur. However, it is also well recognized that use of these tools is not a substitute for human judgment in decision-making. Human judgment comes into play because the structure or findings of an analysis may not be adequate to inform a decision". Ibid., at p. 93.

44 Consumer Product Safety Act, 15 U.S.C. § 2051 
cies to develop and adopt detailed rules or standards to implement these general requirements and objectives consistent with congressional intent (for example, the Consumer Product Safety Commission "may promulgate consumer product safety standards" $\left.{ }^{\prime 4}\right)$. Productrelated regulatory requirements, like all other regulations, must "be based on the best available science." The US regulatory system must (i) allow for public participation and an open exchange of ideas, (ii) promote predictability and reduce uncertainty, (iii) identify and use the best, most innovative, and least burdensome tools for achieving regulatory ends, (iv) take into account benefits and costs, both quantitative and qualitative, (v) ensure that regulations are accessible, consistent, written in plain language, and easy to understand, and (vi) measure, and seek to improve, the actual results of regulatory requirements. ${ }^{46}$ To ensure that these requirements are met, the Office of Information and Regulatory Affairs (OIRA), a Federal agency that is part of the US Office of Management and Budget (OMB) and falls under the President's direction, is in charge of reviewing a wide range of proposed rules. In addition, under the Administrative Procedure Act, stakeholders are granted broad enforceable rights to information on proposed rule-making, to submit comments on draft regulations and receive an agency response, and to initiate judicial review of regulations once adopted. ${ }^{47}$

The EU's current regulatory procedures reflect some features of the US procedure, but there is no overarching administrative procedural legislation. ${ }^{48}$ Unlike in the US, there are no generic binding requirements that regulatory standards must meet. Further, EU regulatory standards are often set by the legislature, and not by downstream regulators pursuant to empowering legislation. Where this is the case, the standards are set in a political process and any change requires legislative amendments. Under the TFEU, policies in the areas of health, safety, environmental protection and consumer protection, are to "take as a base a high level of protection, taking account in particular of any new development based on scientific facts" ${ }^{49}$ Environmental policies are also to be based on the prevention principle, the source reduction principle, the polluter pays principle, and the precautionary principle. ${ }^{50}$ The PP, which is deemed to apply also in the area of health and safety, is effective in both legislative and regulatory procedures.

Unlike most of the other general principles of EU law, the PP is a relatively novel concept. Prior to its incorporation into EU law, it was found only in the legal systems of a few Member States, such as Germany. When the PP was included in the European treaties, no definition was provided, despite the lack of any meaningful tradition in the laws of the Member States. Consequently, considerable controversy remains over its scope of application and meaning, even to this day. As a leading EU law scholar observes, its inclusion in the Treaty leaves "room for disagreement as to which version of the precautionary principle was adopted." ${ }^{51}$ From the first case in which the PP was applied, the Court started off on the wrong footing. "[W]here there is uncertainty as to the existence or extent of risks to human health," the European Court of Justice proclaimed, "the institutions may take protective measures without having to wait until the reality and seriousness of those risks become apparent. ${ }^{\prime 22}$ The problem is that there always is some level of uncertainty, since certainty of the absence of a risk is a logical, empirical, and scientific impossibility. It is thus not surprising that this constitutionally undefined and judicially ill-defined PP has given rise to disputes, ${ }^{53}$ both when regulators invoked it to support stringent measures, ${ }^{54}$ and when they failed to take stringent measures, although the PP arguably authorized or even required them to do so. ${ }^{55}$

45 Consumer Product Safety Act, 15 U.S.C. § 2056

46 Executive Order 13563 of January 18, 2011, Improving Regulation and Regulatory Review, Federal Register, Vol. 76, No. 14 Friday, 21 January, 2011, at Sections, 1(a), 2(a)-(b).

475 USC § 553(c) (Rule making); 5 USC § 556 and 5 USC § 557 (When rules are required by statute to be made on the record after opportunity for an agency hearing).

48 Peter Strauss, Turner Smith and Lucas Bergkamp, Rulemaking, Administrative Law of the European Union (New York: ABA Publishing, 2008).

49 Article 114(3), TFEU.

50 Article 191(2), TFEU (ex Article 174 TEC) merely declares that the EU's environmental policy "shall be based on the precautionary principle."

51 Paul Craig, EU Administrative Law. Second Edition (Oxford: Oxford University Press, 2012), at p. 666.

52 Case C-180/96, UK v Commission (1998) ECR 1-2265, at 99 " When there is uncertainty as to the existence or extent of risks to human health, the institutions may take protective measures without having to wait until the reality and seriousness of those risks becomes fully apparent").

53 Roel Pieterman, Jaap C. Hanekamp and Lucas Bergkamp, "Onzekere voorzorg bedreigt de rechtszekerheid", 1 Nederlands Juristenblad (2006),:pp. 2-8.

54 For an overview of the case law, see Paul Craig, EU Administrative Law. Second Edition (Oxford: Oxford University Press, 2012), pp. 641-667.

55 See, for instance, Case C-236/01, Monsanto Agriculturu ItaUa SpA v Presidenza del Consiglio dei Ministri (2003) ECR 1-8105 Case C-6/99, Association Greenpeace Frmice v Ministere de I'Agriculture et de la Peche (2000) ECR 1-1651. Case C-393/01, France $v$ Commission (2003) ECR 1-5405. 


\section{The Precautionary Principle's Influence on the EU Regulatory Process}

Having close philosophical relations ${ }^{56}$ with postmodernism, ${ }^{57}$ the PP reflects dissatisfaction with non-transparent, non-participatory, and slow decision-making by technocrats based on conventional scientific paradigms that requires high strength of causal evidence. ${ }^{58}$ In this view, regulatory action was often deemed to be 'too little, too late.' According to some proponents, the PP would require that the EU institutions open up their regulatory procedures, and take timely and stringent regulatory measures in the face of uncertain science. While evidence is lacking, there is ardent belief in the PP's power. In one of the recitals of the REACH Regulation, the EU legislature goes so far, without any basis in fact, as to equate the PP with increased health and environmental protection. ${ }^{59}$ It is unclear, however, how the PP's application could have any such salutary effects. US experts have been particularly critical. For one, the former Administrator of the influential OIRA, which is responsible for review of federal regulations, has called the PP a paralyzing principle. ${ }^{60} \mathrm{~A}$ leading academic, who is an expert on environmental and global is-

56 Roel Pieterman and Jaap C. Hanekamp, The cautious society? An essay on the rise of the precautionary culture (Amsterdam: HAN Foundation, 2002). Barbara Stark, "Sustainable Development and Postmodern International Law: Greener Globalization?", 27 Wm. \& Mary Envrtl. L. \& Pol'y Rev. (2002), 137 et sqq, at pp. 156-157. Sustainable Development Education Panel First Annual Report 1998, Annex 4 - Submission to the Qualifications and Curriculum Authority, at p. 13; Royden Somerville QC, "Legal Opinions: Managing Risks Associated with Outdoor Use of Genetically Modified Organisms", January 2013, at p. 24; Laurence Boisson de Chazournes, "Precaution in International Law - Reflection on its Composite Nature", in Tafsir Malick Ndiaye, Rüdiger Wolfrum and Chie Kojima (eds), Law of the Sea, Environmental Law and Settlement of Disputes: Liber Amicorum Judge Thomas A. Mensah (Amsterdam: M. Nijhoff, 2007), at pp. 21-24; "The Many Facets of Precautionary Logic", Introduction, 2 Erasmus Law Review (2002), pp. 97 et sqq, at p. 102; Jaap C. Hanekamp, "Neither Acceptable nor Certain - Cold War Antics for 21st Century Precautionary Culture", 2 Erasmus Law Review (2009), pp. 242-244; Jerry Ravetz, "The Post-Normal Science of Precaution", 36 Futures (2003), pp. 347 et sqq, at p. 350; David Vogel, The Politics of Precaution: Regulating Health, Safety, and Environmental Risks in Europe and the United States, (Princeton: Princeton Univ. Press 2012), at p. 27.

57 A founder of post-modernism, Foucault denies that there is universal rationality, and suggests that any knowledge, including scientific knowledge, reflects specific interests and serves as an instrument for domination. "The theme that underlies all Foucault's work is the relationship between power and knowledge, and how the former is used to control and define the latter. What authorities claim as 'scientific knowledge' are really just means of social control." Philip Stokes, Philosophy: 100 Essential Thinkers (London: Arcturus, 2004), at p. 157 (discussing the theories of Michel Foucault). See also Michel Foucault, The Birth of Biopolitics: sues, has opined that the PP's meaning remains obscure. ${ }^{61}$ He argued that "the adverse effects of activities are never 'fully understood"” and thus "the directive would be: 'Don't do anything." Neither the European courts' case law nor the Commission Communication ${ }^{62}$ have been able to effectively rebut these fundamental concerns. We encounter here of the paradoxes of the PP: although the PP promises to guide decision makers, it is unable to provide direction, which induces opportunities for decision making on elements other than scientific facts.

It has been argued, however, that the PP is not merely useless, but positively harmful. ${ }^{63}$ The PP's adverse implications are their most visible in its 'strongest' version, which is triggered once "there is at least prima facie scientific evidence of a hazard," rather than a risk. ${ }^{64}$ This PP version challenges Enlightenment era regulatory science protocols, and the rationalist approach of risk regulation, in the face of scientific uncertainty. As scientific uncertainty, unfortunately, is ubiquitous, its potential scope of application is enormous. In this version, the PP creates an administrative presumption of risk which favors ex ante regulation, and tends to reverse the administrative and adjudicatory burden of proof (production and persuasion) from government to show potential

Lectures at the Collège de France, 1978-1979, Translated by Graham Burchell, (London: Palgrave Macmillan, 2008).

58 For a discussion of the various versions of the PP, see Lucas Bergkamp, EC Law for the New Economy (Antwerpen: Intersentia, 2003), pp. 157-231.

59 REACH Recitals 9 and 69; Art. 1(3).

60 Cass R. Sunstein, "The Paralyzing Principle", Regulation (Winter 2002-2003), pp. 32-37.

61 Christopher D. Stone, "Is There A Precautionary Principle?", 31 ELR (2001)

62 European Commission. Communication from the Commission on the Precautionary Principle. $\operatorname{COM}(2000) 1$ final, Brussels, 2.2.2000

63 See, for instance, Giandoemnico Majone, "What Price Safety? The Precautionary Principle and its Policy Implications", 40 JCMS (2002), p. 89 et sqq; K-H. Ladeur, "The Introduction of the Precautionary Principle into EU Law: A Pyrrhic Victory for Environmental and Public Health Law?", 40 CMLRev (2003), p. 1455 et sqq. Forrester, "The Dangers of too much Precaution", in M. Hoskins and W. Robinson (eds), A True European, Essays for Judge David Edward (Oxford: Hart, 2003) ch 16. G. Marchant and K. Mossman, "Arbitrary and Capricious: The Precautionary Principle"; 11 The European Union Courts (AEI Press, 2004).

64 Peter Saunders, "The Precautionary Principle", in Organization for Economic Cooperation and Development, Policy Responses to Societal Concerns in Food and Agriculture, Proceedings of an OECD Workshop (2010), at pp. 47, 52. Federal Republic of Germany, Federal Institute for Risk Assessment, Evaluation of Communication on the Differences Between 'Risk' and 'Hazard', (E. Ulbig et al. eds., 2010), at pp. 7-8 (defining and distinguishing between the terms "hazard" and "risk"). 
harm to industry to show no potential of harm. Consequently, since it is impossible to prove the absence of risk, the outcome invariably is that the hazard is regulated. ${ }^{65}$ Where the burden of proof initially rests on the regulator, the strict reliance on peer-reviewed scientific evidence ${ }^{66}$ is replaced with use of broader, qualitative, rather than quantitative, evidence, and a 'weight-of-the-evidence,' rather than 'strength-of-the evidence,' approach at the regulatory level. ${ }^{67}$ This PPdriven process equates a precautionary inference with the best explanation. ${ }^{68}$ Where quantitative evidence is not available, the standard of proof for the government shifts from causation to correlation. In this process, scientific experts are to facilitate greater understanding of the multiple "dimensions of mixed questions of fact and law that frequently characterize scientific disputes. ${ }^{169}$ Furthermore, regulatory decisions remain open, non-final and subject to continuous reassessment pending new scientific developments. $^{70}$

While some of the dissatisfaction with EU regulatory procedures was justified, the changes engendered by the PP went far beyond resolving the deficiencies. Consistent with post-modern skepticism about universal reason and empirical science, the PP reduced the role of scientific evidence and paved the way for 'other legitimate factors, ${ }^{71}$ such as culture and values. As Alemanno aptly observes, this trend "although highly contested - given its inherent unpredictability -, (...) expresses a variety of wisdoms

65 Hazard-based restrictions can be found in EU regulation of chemicals, cosmetics, medical devices, plant protection products, biocides, toys, food contact materials, etc. If no derogations are available under the particular regulation, the absence of risk is completely irrelevant and does not affect the restriction. In addition to hazard-based restrictions, the EU also regulates on the basis of proxies or surrogates for exposure and risk, and assumed exposure and risk. Lucas Bergkamp (ed.), The European Union REACH Regulation for Chemicals: Law and Practice (Oxford: Oxford University Press, 2013), pp. 420-422 ("Hazard and Risk Revisited").

66 Peter Saunders, The Precautionary Principle, in Organization for Economic Cooperation and Development, Policy Responses to Societal Concerns in Food and Agriculture, Proceedings of an OECD Workshop (2010), at p. 55.

67 Joel Tickner, "Putting Precaution into Practice: Implementing the Precautionary Principle", in Integrating Foresight and Precaution into the Conduct of Environmental Science, Report of the International Summit on Science and the Precautionary Principle (Sept. 20-22, 2001).

68 Carl Cranor, "Scientific Inferences in the Laboratory and the Law", 95 American Journal of Public Health (2005), at S-121, S-123.

69 Caroline Foster, Scientific Evidence and the Precautionary Principle in International Courts and Tribunals, 2010 Salmon Lecture (hereinafter referred to as "Caroline Foster, Salmon Lecture") (Sept. 2, 2010) at p. 6. that fail to be apprehended by the rationale soul." ${ }^{72}$ According to a recent European Environmental Agency report, "the PP can trigger the examination of wider issues, moving away from narrow questions of risk (...) to broader questions about the future (...) and public engagement." In this view, the PP "triggers broad debates about what kind of future we want" and "what innovation pathways could lead towards such futures." ${ }^{73}$ Clearly, innovation is not confined to the EU and the US has much at stake in EU decision making on innovation. And, more importantly, where the discussion ventures into the kind of future we want, we have left the realm of science.

Ironically, while the EU has begun to rethink the $\mathrm{PP}$ and its use, the US seems to be moving towards it. In November 2013, the EU Chief Scientist expressed concerns about the PP's "inappropriate use and how it is used politically to stop something from happening," and therefore called for its reexamination. ${ }^{74}$ At the same time, the Obama administration might be willing to entertain PP-based analysis. With respect to deep seabed mining policy, the US government referred to the 'precautionary approach', but, in practice, arguably applied the precautionary principle. ${ }^{75}$ In addition, in an August 2013 oversight hearing on transparency and sound science, the US House of Representatives' Committee on Natural Resources highlighted 'scientific inadequacy' in regulatory decision making under the Endangered Species Act. ${ }^{76}$ In light of USTR's Froman's comments that the

70 Ibid, at pp. 7, 20

71 We treat the "other legitimate factors" as inherent in, albeit not exclusive to, PP-based regulatory procedure.

72 Alberto Alemanno, "Risk vs. Hazard and the Two Souls of EU Risk Regulation: A Reply to Ragnar Löfstedt", 2(2) European Journal of Risk Regulation (2011), pp. 169-171. "Therefore it is no surprise that today the resulting tension between the necessity for a rational, evidence-based decision-making and the wider demand for a flexible, precautionary-oriented regulatory approach stands as the defining feature of the EU risk regulation. In particular, by allowing restrictive regulatory action in situations of documented scientific uncertainty, the precautionary principle embodies the uneasy coexistence between the two souls."

73 European Environment Agency, "Late lessons From Early Warning: Science, Precaution, Innovation", EEA Report No. 1/2013, at p. 644.]

74 "EU chief scientist calls for debate on precautionary principle", Chem Watch, 7 November 2013.

75 Lawrence Kogan, "Revised U.S. Deep Seabed Mining Policy Reflects UNCLOS and Other International Environmental Law Obligations", Emerging Issues (2013), 6893.

76 US House of Representative, Committee on Natural Resources. Oversight Hearing on "Transparency and Sound Science Gone Extinct?: The Impacts of the Obama Administration's Closed-Door Settlements on Endangered Species and People", 1 August 2013. 
distinction between the precautionary principle and cost-benefit analysis is "decreasingly important," the data quality issues might be more than incidental.

\section{The Postmodern Revenge: Precautionary Principle's Effects on Science}

In addition to reducing the role of science, however, the PP has also changed science itself. In the late 1990s, post-modernism, as a science, suffered a serious blow in the US following a leading postmodern journal's publication of a satirical pseudo-scientific hoax article submitted by a critic. ${ }^{77}$ This debunking of post-modernist science had much more limited impact in Europe, however, and the European movement has been able to strike back through the PP.

Because the PP lowers the evidentiary standard of proof, it has the potential to affect the practice of science. The risk is that the PP does not promote 'science-based policy', but rather, 'policy-based science'. Negative study results do not support policy making, while positive results make a study (and the researchers who conducted it) politically relevant. If researchers are sensitive to such attention, they may be inclined to select a methodology that is more likely to generate a positive result. In addition, the PP overemphasizes 'worst case scenarios' and underemphasizes probabilistic assessment, the combination of which leads to a focus on the magnitude of extreme outcomes in theory. In this respect, the PP creates a paradox: although it is intended to help society reduce risk, it causes higher perceived risk levels

77 Alan Sokal, "Transgressing the Boundaries: Toward a Transformative Hermeneutics of Quantum Gravity", Social Text 46/47, pp. 217-252 (Spring/Summer 1996). (the original "parody" article). See also Alan Sokal, "A Physicist Experiments with Cultural Studies", Lingua Franca, May/June 1996, pp. 62-64 (the article in which the parody is revealed). Cf. Alan Sokal, Beyond the Hoax: Science, Philosophy and Culture (Oxford: Oxford University Press, 2008).

78 Under various Framework Programmes, the European Commission provides very substantial amounts of funding for research intended to support policy making. See $<$ http://ec.europa.eu/research/environment/index en.cfm $>$ (last accessed on 26 November 2013). For instance, "European Union (EU)-funded research was instrumental in substantiating the plausibility that endocrine disrupters might lead to serious, irreversible human and wildlife health effects." (emphasis supplied) The 2013 Berlaymont Declaration on Endocrine Disrupters.

79 Dietrich, R., Aulock, S.v., Marquardt, H., Blaauboer, B., Dekant, W., Hengstler, J., Kehrer, J., Collier, A., Gori, G.B., Pelkonen, O., Nijkamp, F.P., Lang, F., Stemmer, K., Li, A., Savolainen, K., Wallace, Hayes, A., Gooderham, N., Harvey, A., "Scientifically unfounded precaution drives European Commission's recommen- by drawing attention to non-quantified worst cases. No matter how research has been conducted and what results it generated, it is always possible (and not incorrect) to conclude that "product A may cause adverse effect B." The answer to the question whether "it can be excluded that product A causes any adverse effect" is, by definition, negative. Thus, the PP has the potential to affect (i) what issues are being researched, (ii) how scientific issues are researched, and (iii) how scientists express their findings and conclusions. With the funding of academic research increasingly shifting from direct funding to project-based funding and thus more research being conducted to satisfy the informational needs of regulators, ${ }^{78}$ these effects are augmented. This analysis might help to explain the controversy over some studies on endocrine disrupting chemicals. ${ }^{79}$ Indeed, it is telling that one of the conclusions of a scientific consensus meeting hosted by the EU Commission's Chief Scientist is that ' $[\mathrm{i}] \mathrm{t}$ is possible that thresholds do not exist. $^{80}$ Is this negative statement about mere possibility a scientific conclusion at all? In any event, if it is inconsistent with any plausible model of endocrine disruption to argue that one molecule of a disruptor can cause an adverse effect, thresholds above zero must be deemed to exist, even though they may be so low that they fall below detection limits. ${ }^{81}$

Although not unique to the EU, ${ }^{82}$ the PP may well aggravate the risk of 'precautionary policy-driven science.' And the problem is not easily correctable. To the extent the PP results in unreliable scientific studies, these studies are not necessarily offset by other, sound studies. In a meta-analysis of a number of studies, for instance, the issue of 'garbage in, garbage out'

dations on EDC regulation, while defying common sense, wellestablished science and risk assessment principles", Toxicology in Vitro (2013), doi: <http://dx.doi.org/10.1016/j.tiv.2013.07.001> (last accessed on 26 November 2013).

80 Office of the Chief Scientific Adviser, European Commission, Meeting on endocrine disruptors, Brussels, 24.10.2013. The reasoning represents a non sequitur: "There was agreement that the existence of thresholds cannot be determined experimentally. For this it would be necessary to look at much smaller doses, with correspondingly smaller effects, beyond the resolving power of toxicological experiments. It is therefore uncertain whether there are thresholds at all, at least for some endpoints."

81 The comparison with genotoxic chemicals made in the minutes is not applicable, unless it has been established that the endocrine effect results from the genotoxic effect. Office of the Chief Scientific Adviser, European Commission, Meeting on endocrine disruptors, Brussels, 24.10.2013.

82 Richard Lindzen, "Science in the Public Square: Global Climate Alarmism and Historical Precedents", 18(3) Journal of the American Physicians and Surgeons (2013), pp. 70-73. 
(also known as 'GIGO') arises, as the unsound studies are more likely to generate positive results. ${ }^{83}$ Further, in a 'weight of the evidence,' as opposed to 'strength of the evidence' approach, ${ }^{84}$ unsound studies also bear on the final outcome. This is another paradox of the PP: the PP requires the reduction of scientific uncertainty, but it actually increases such uncertainty.

As noted above, the US regulatory process has not experienced a similar post-modern influence. Postmodernism was not completely absent in the US, ${ }^{85}$ but never achieved the same stature as it did in Europe. There was also a very strong countervailing force in the US in the form of rational choice theory. As Oppenheimer explains, in the US, "in the early $21 s t$ century, rational choice theory has become the paradigmatic way of analyzing behavior. Three relatively independent fields have evolved with rational choice theory at their core: game theory, social choice theory, and decision theory." 86

A similar trend is apparent in EU impact assessment, which, compared to US-style cost-benefit analysis, is more qualitative than quantitative and aimed at identifying and assessing also intangible socio-economic and cultural effects. ${ }^{87}$ In addition, a 2007 Commission study identified significant differences between the EU impact assessment and US regulatory impact analysis, "particularly as regards the legal and institutional framework, the resulting different stages at which [assessments] are produced, and the difference in purpose they serve in the two systems." Consequently, performing one joint ex-ante assessment on a comparable initiative to be used by both US regulators and the Commission would be "an immensely challenging task." ${ }^{88}$ Common sense dictates that the EU and US identify and iron out these differences so that assessments can be shared. ${ }^{89}$

The EU's current post-modern regulatory process would not appear to be consistent with the US' emphasis on rational choice. Rational choice requires high quality, state-of-the-art science based on sound methodology. Both the EU and US have a substantial interest in such science. It would be unfortunate if the regulators of one of the trading blocks are not comfortable relying on scientific studies conducted in the other trading block. In the area of risk regulation, there is an indisputable need for mutual trust in science, which requires also transparency in relation to the circumstances under which such science was conducted. This applies also to risk assessment, and, to some extent, to risk management option analysis. The TTIP can play a key role in creating a framework that will enable the sharing of scientific resources. However, the PP's effects will first need to be identified and debated.

Although viewed by PP advocates as a cause of the problem, science can help to transcend this PP quandary. Despite the precautionary rhetoric, science can probably demonstrate how the high standards both regions impose ensure a high level of consumer, health, and environmental protection. Scientists also may be able to show that, in many instances, differences in regulatory standards between the EU and US are not grounded in science. Once this reality has been revealed, the EU will find it difficult to insist on the superiority of PP-based regulations. Are Europe's citizens really willing to forego the substantial economic benefits the TTIP could bring to safeguard undefined cultural values that engender a reduced role for science in risk regulation?

\section{The Reality of Precaution}

In an attempt to discredit the TTIP negotiations and scare Europeans, Friends of the Earth has not so sub-

83 Conversely, the sound studies are more likely to produce negative results. The end result may be that the meta-analysis will find a correlation.

84 Sheldon Krimsky, "The Weight of Scientific Evidence in Policy and Law," 95 American Journal of Public Health, Supplement 1 (2005), at S-129 (distinguishing between the 'weight-of-the evidence' and 'strength-of-evidence' approaches); Jack Weinberg and Joe Thornton, "Scientific Inference and the Precautionary Principle", in International Joint Commission, "Applying Weight of the Evidence - Issues and Practice: A Report From the Workshop Held October 24, 1993", (Michael Gilberston and Sally Cole-Misch, Eds. June 1994) at pp. 20-21, 24-26 (explaining the need to employ the "weight-of-the-evidence" approach to implement the precautionary principle).

85 Alan Sokal and Jean Bricmont, Fashionable Nonsense (St. Martin's Press, 1998). Bernard D. Goldstein and Russellyn S. Carruth, "Implications of the Precautionary Principle for Environmental Regulation in the United States: Examples from the Control of Hazardous Air Pollutants in the 1990 Clean Air Act Amendments", 66 Law and Contemporary Problems (2003), p. 247 et sqq, at p. 249.

86 Joe A. Oppenheimer, "Rational Choice Theory", in The Sage Encyclopedia of Political Theory (2008)

87 European Commission, "Impact Assessment Guidelines", SEC(2009) 92, Brussels, 15 January 2009.

88 Cavan O'Connor Close and Dominic J. Mancini, "Comparison of US and European Commission Guidelines on Regulatory Impact Assessment/Analysis", 3 Industrial Policy and Economic Reforms Papers (2007), Enterprise and Industry Directorate-General, European Commission, Brussels, April 2007.

89 John F. Morrall III, "Determining Compatible Regulatory Regimes between the U.S. and the EU, US Chamber of Commerce", 2012. 
tly suggested that the EU might 'trade away' its health and environmental protection. ${ }^{90}$ It argues that strict scientific risk assessment and economic cost-benefit analysis requirements could undermine PP implementation for human health and environmental regulatory purposes. Meanwhile, the European consumer organization and transatlantic consumer dialogue have expressed "consumer concerns" over food, medicines, consumer goods and internet sales. ${ }^{91}$

Despite the long list of scandals, crises, and scares in the EU involving environmental, health and safety issues, ${ }^{92}$ these interest groups now suggest that the EU is a much safer place to live, work, and eat than the US. Of course, it is possible that the regulatory responses to past scandals have been so effective that actual risks have dropped substantially; but, do we have the empirical evidence to support that claim? For instance, the EU's stance on the health effects of US meat containing hormone residues is not supported by science, ${ }^{93}$ notwithstanding the Commission's parsimonious assertion that allowing

90 Magda Stoczkiewicz, "Trading Away Citizen and Environmental Safeguards", European Voice, 10 October 2013.

91 BEUC and TACD, EU-US Trade Talks Resume, Consumer Concerns Continue, PR 2013/024, 12 November 2013.

92 Tim Knowles and Richard Moody, "European Food Scares and Their Impact on EU Food Policy", 109(1) British Food Journal (2007), pp. 43-67.

93 The WTO dispute resolution bodies, in first instance and on appeal, found the EU import ban on meat that contains artificial hormones trade-illegal, but the EU has failed to comply with these rulings. In the Appellate Body's opinion, "the European Communities did not actually proceed to an assessment (...) of the risks arising from the failure of observance of good veterinary practice combined with problems of control of the use of hormones for growth promotion purposes. The absence of such risk assessment, when considered in conjunction with the conclusion actually reached by most, if not all, of the scientific studies (...), leads us to the conclusion that no risk assessment that reasonably supports or warrants the import prohibition embodied in the EC Directives was furnished to the Panel." WTO Appellate Body, EC Measures Concerning Meat and Meat Products (Hormones), AB-1997-4 (16 January 1998). Following this ruling, the EU mandated a risk assessment, amended the relevant legislation, but upheld the ban, claiming it complied with its international law obligations. The US retaliated. In 2009, the USTR and the European Commission entered into an agreement that provides for an increase of EU import quota for beef produced from cattle that have not been treated with growth-promoting hormones. The deal was approved by the European Parliament in March 2012. European Parliament News, Win-win ending to the "hormone beef trade war," available at <http://www.europarl.europa.eu/news/en/news-room/content/20120314IPR40752/html/Win-win-ending-to-the-hormonebeef-trade-war> (last accessed on 26 November 2013). Cf. Howard F. Chang, "Risk Regulation, Endogenous Public Concerns, and the Hormones Dispute: Nothing to Fear but Fear Itself", $77 \mathrm{~S}$. Cal. L. Rev. (2003-2004), p. 743 et sqq. Jayson L. Lusk, Jutta Roosen, and John A. Fox, "Demand for Beef from Cattle Administered Growth Hormones or Fed Genetically Modified Corn: A Comparison of Consumers in France, Germany, the United King- such meat imports would "compromise the health of [EU] consumers for commercial gain. ${ }^{\prime 94}$ Further, risk regulation involves risk/risk trade-offs, which present complicated issues and challenge even good regulators. A major limitation of the $\mathrm{PP}$ is that it is ill-equipped to address risk/risk trade-offs, although they feature prominently in virtually any policy decision. ${ }^{95}$ In light of this shortcoming and the PP's paradoxes and adverse effects, the assumption that the PP has rendered EU product standards more protective of health and the environment than corresponding US product standards, however, remains unsubstantiated.

To begin with, the US is not known for lax product standards and health and safety regulations, and has a very stringent civil liability system. ${ }^{96}$ In reality, both the EU and US have imposed stringent standards to protect the environment and public health from potentially harmful products, processes and activities, with each drawing conclusions, sometimes earlier than the other, from "suspected but not completely substantiated relationship between facts, dom, and the United States", 85(1) Am. J. Agr. Econ. (2003), pp. 16-29. The trade dispute over poultry treated with chlorine is still pending. WTO Dispute Settlement, European Communities Certain Measures Affecting Poultry Meat and Poultry Meat Products from the United States, DS389. Cf. Congressional Research Service, U.S.-EU Poultry Dispute on the Use of Pathogen Reduction Treatments (PRTs), 7-5700, R40199 (November 19,2012).

94 European Commission, "TTIP Questions and Answers", available at <http://ec.europa.eu/trade/policy/in-focus/ttip/questions-andanswers/> (last accessed on 26 November 2013).

95 John D. Graham and Jonathan Baert Wiener (eds), Risk vs. Risk: Tradeoffs in Protecting Health and the Environment (Cambridge: Harvard University Press, 1995).

96 The problem of "junk science" however, has plagued litigation in US courts. Peter Huber, Galileo's Revenge: Junk Science In The Courtroom (New York: Basic Books, 1993). For a comparison of European and US product liability litigation, see Lucas Bergkamp and Rod Hunter, "Product Liability Litigation in the US and Europe: Diverging Procedure and Damage Awards", 3 Maastricht Journal of International and Comparative Law (1996). When it proposed the REACH Regulation, the Commission suggested that stringent ex ante precautionary regulation of chemicals would be required due to the insufficient incentives generated by European civil liability regimes. "Liability is usually based on the principle that those who cause damage should pay compensation for that damage. However, in order to be held liable, it is generally required that a causal connection be proven between the cause and the resulting damage. This is often virtually impossible for injured parties if cause and effect occur far apart in time and if adequate test data on the effects of substances are not available. Even if a causal connection can be established, compensations awarded by courts of EU Member States are generally not as high as, for example, in the US, and hence have a limited deterrent effect. In order to improve this situation and to make producers assume responsibility for their products, the Commission has announced its intention to propose Community legislation in this field." European Commisison, WHITE PAPER Strategy for a Future Chemicals Policy, COM(2001) 88 final, Brussels, 27.2.2001, pp. 6-7. 
from trends among facts, from theoretical projections from imperfect data...and the like." ${ }^{\prime 97}$ There is a difference, however, between the EU and US approaches. As Vogel puts it, "the role of precaution in shaping American consumer and environmental risk regulation is best understood as a preference or approach, rather than, as it became in the $E U$, a legal doctrine or principle. ${ }^{\prime 98}$ Vogel largely attributes this distinction to the relative regional differences in (i) environmental NGO and Green Party political influence, (ii) public perceptions of and confidence in government, science and technology, and industry; and (iii) the 'false negative' regulatory failures previously experienced in Europe as compared to the US experience with 'false positives' ${ }^{99}$ He concludes that such differences have resulted in relatively more stringent and risk-averse European regulations. ${ }^{100}$ These conclusions have not been confirmed by a study conducted by Wiener and others entitled "The Reality of Precaution." This study analyzed a wide range of US and EU risk regulations, but found no one-directional differences in precautionary regulation between the two regions. ${ }^{101}$ At the same time, the findings of the 2010 Attali Commission ${ }^{102}$ and the 2012 Gallois reports ${ }^{103}$ have documented adverse impacts of EU PP-based regulations. ${ }^{104}$ These reports describe how regulations employed to curtail the use of chemical substances and novel technologies have hampered science and technological development, entrepreneurial risk-taking and economic growth, contrary to the neo-economic liberal Lisbon Agenda. Taking the debate to its logical extreme, the European Risk Forum, an expert-led not-for-profit think tank based in Brussels, recently proposed an innovation

97 David Vogel, The Politics of Precaution: Regulating Health, Safety, and Environmental Risks in Europe and the United States, (Princeton: Princeton Univ. Press 2012), at p. 255, quoting Martin Shapiro, "The Frontiers of Science Doctrine: American Experiences with the Judicial Control of Science-Based Decision-Making" in C. Joerges, K.M. Ladeur, and Kim Voss (eds), Integration Scientific Expertise into Regulatory DecisionMaking (Baden-Baden: Nomos Verlagsgesellschaft 1997), pp. 332-333.

98 Ibid., at p. 255 (emphasis added).

99 David Vogel, "The Politics of Risk Regulation in Europe and the United States", 3 The Yearbook of European Environmental Law (2003), at pp. 50-54

100 Ibid., at p. 67; David Vogel, The Politics of Precaution: Regulating Health, Safety, and Environmental Risks in Europe and the United States, (Princeton: Princeton Univ. Press 2012), at p. 30.

101 Jonathan B. Wiener, Michael D. Rogers, James K. Hammitt, and Peter H. Sand, The Reality of Precaution (Washington DC: Resources for the Future, 2010). principle' to counteract the PP's negative effects on innovation. ${ }^{105}$

Even though the PP, as the Wiener study suggests, is not the sole cause of more stringent regulations, it is a cause that has been institutionalized and made part of the EU legal order thereby gaining 'trump card' status and enabling the government to skew the regulatory process. At the same time, the PP's institutionalization makes it harder for the EU to concede that US standards are as protective as the EU standards. Of course, the PP can only be invoked selectively; but where it is invoked, concerns about protectionism invariably arise. But even assuming PPbased regulations result in a reduced rate of false negatives (i.e. not regulating where there is a risk that should be regulated), there will also be a substantial increase in false positives (i.e., regulating a non-existent risk or a risk that should not be regulated). Since both protectionism and false positive risks are trade concerns, there would appear to be a key role for the TTIP negotiators.

\section{The Bottom Line: The US and EU Can Learn From Each Other}

With the growth of the American administrative state, the US regulatory system has had its transparency deficiencies too. ${ }^{106}$ Moreover, US regulatory procedure continues to evolve and, as noted above, under the Obama administration it is undergoing slight changes that bring it a bit closer to the EU system. For instance, the US now also considers qualitative data, in addition to quantitative data, in regulatory decision mak-

102 Attali Commission, An Ambition for Ten Years - Report of the Committee for the Liberation of Growth, Chaired by Jacques Attali (October 2010), at pp. 21-23, 34-35, 157, 175-177.

103 Louis Gallois, "Compact for the Competitiveness of French Industry, Report to the Prime Minister", 5 November 2012, at p. 39.

104 It is hard to pinpoint the PP as he sole cause for such adverse impacts, as other trends (such as 'risk society' politics) and arguments may also push towards ever stringent regulation. It is clear, however, that the PP, being a constitutional policy principle, provides substantial power to proponents of such regulation.

105 ERF, The Innovation Principle - Letter to the Presidents of the European Commission, the Europe Council, and the European Parliament. European Risk Forum - Communication 12, Brussels, October 2013.

106 Richard A. Epstein, "Why The Modern Administrative State is Inconsistent With the Rule of Law", 1 NYU Journal of Law \& Liberty (2008), at pp. 491-492 and 505-515; Jessica Mantel, "Procedural Safeguards for Agency Guidance: A Source of Legitimacy for the Administrative State", 61 Administrative Law Review (2009),p. 343 et sqq, at p. 347. 
ing. ${ }^{107}$ Some of the ideas behind the PP could prove useful in further reforming the US regulatory process. For instance, the US system provides for 'notice-andcomment' without the agency indicating what information it needs, which often results in large numbers of people submitting identical letters to protest against or support a proposed rule. Increasingly, in its consultation procedures, ${ }^{108}$ the EU Commission and agencies use a questionnaire that stakeholders are requested to complete, which provides a wealth of information to decision makers. ${ }^{109}$ This EU practice would also add value to the US. In furtherance of Executive Order 13563, a discussion about where and when risk quantification is either impossible or not useful, and how such problems should be handled, would be helpful. The parties, furthermore, could explore rules on the use of safety factors that incorporate "an appropriate degree of precaution" where there are profound uncertainties regarding the nature and significance of particular risks, the magnitude and severity of known and/or uncertain potential harms, the degree and certainty of human exposure to such harms and the vulnerability of the various groups (populations) so exposed, ${ }^{110}$ and how the degree of reversibility of potential harm can be reliably assessed. A thorough review

107 Executive Order 13563, supra at Sec. 1(c) ("In applying [the] principles [set forth in 1(a)-(b)], each agency is directed to use the best available techniques to quantify anticipated present and future benefits and costs as accurately as possible. Where appropriate and permitted by law, each agency may consider (and discuss qualitatively) values that are difficult or impossible to quantify, including equity, human dignity, fairness and distributive impacts.").

108 On-going and closed public consultations by the Commission are listed on the 'Your Voice' website at <http://ec.europa.eu/yourvoice/consultations/index_en.htm $>$ (last accessed on 26 November 2013).

109 Peter Strauss, Turner Smith and Lucas Bergkamp, Rulemaking, Administrative Law of the European Union (New York: ABA Publishing, 2008).

110 John Graham, "The Role of Precaution in Risk Assessment and Management: An American's View", remarks prepared for the January 11-12, 2002 conference on Europe, Precaution and Risk Management: A Comparative Case Study Analysis of the Management of Risk in a Complex World, pp. 1-4.

111 European Parliament Resolution 2012/2024(INL) - 15/01/2013 recommending to the Commission a Law of Administrative Procedure of the European Union. Cf. European Law Institute, Towards Restatement and Best Practices Guidelines on EU Administrative Procedural Law.

112 The EU has adopted a document access regulation, but it excepts "[a]ccess to a document, drawn up by an institution for internal use or received by an institution, which relates to a matter where the decision has not been taken by the institution (...) if disclosure of the document would seriously undermine the institution's decision-making process, unless there is an overriding public interest in disclosure." Regulation (EC) No 1049/2001 of the European Parliament and of the Council of 30 May 2001 regard- of the weight-of the-evidence approach would also be helpful, including when and how it may be used; it is particularly important to agree on specific standards for deciding what data and studies may be included, and how weighing is to be done.

Conversely, there are lessons the EU can learn from US science-based policy making. As the EU is currently working on its own general administrative procedure laws, ${ }^{111}$ it has an interest in understanding the US requirements regarding records on file with the agency and public access thereto. ${ }^{112}$ Under the US system, proposed regulations are to be based on information that is in the agency's files ('on record'), and no extraneous documents may be relied on. ${ }^{113}$ Unless an exception applies, the public has access to a US agency's records. In the EU, the practice has been for regulators to rely on documents that are not in its files, are added only late in the procedure after stakeholder consultation, or are kept secret for the regulator's convenience. By and large, the European courts have tolerated this practice. ${ }^{114}$ Similar issues arise with respect to risk assessment reports. A rule requiring that all facts and evidence that the regulator invokes to support a proposed measure be part of the record, and be made publically available,

ing public access to European Parliament, Council and Commission documents, OJ L L 145/43 (31.5.2001). There is also a webbased 'comitology register,' which provides access to draft measures subject to adoption through the comitology procedure, at $<$ http://ec.europa.eu/transparency/regcomitology/index.cfm > (last accessed on 26 November 2013).

1135 U.S.C. $\S 553(\mathrm{c})$, which is Section 4(b) of the Administrative Procedure Act (APA), provides as follows: "After notice required by this section, the agency shall afford interested persons an opportunity to participate in the rule making through submission of written data, views, or arguments with or without opportunity to present the same orally in any manner; and, after consideration of all relevant matter presented, the agency shall incorporate in any rules adopted a concise general statement of their basis and purpose. Where rules are required by statute to be made on the record after opportunity for an agency hearing, the requirements of sections 7 and 8 shall apply in place of the provisions of this subsection." 5 U.S.C. $\$ 556(\mathrm{e})$, which is Section 7(d) of the APA, on the record of hearings, provides as follows: "The transcript of testimony and exhibits, together with all papers and requests filed in the proceeding, shall constitute the exclusive record for decision in accordance with Section 8 and, upon payment of lawfully prescribed costs, shall be made available to the parties." Cf. Attorney General's Manual on the Administrative Procedure Act, Prepared by the United States Department of Justice Tom C. Clark, Attorney General, 1947. ACUS, Administrative Conference Recommendation 2013-4: The Administrative Record in Informal Rulemaking, 14 June 2013.

114 See, for instance, for a recent case Case T-456/11, International Cadmium Association (ICdA) et al. v European Commission, 14 November 2013 (holding that "[t]he procedure culminating in the amendment of Annex XVII to Regulation No 1907/2006 and that relating to the request for access to the Commission's documents under Regulation No 1049/2001 are separate procedures which are not mutually interdependent."). 
except to the extent that exceptions apply, deserves serious consideration. Diverted by its own institutional incentives, the Commission may not be supportive of rules that impose restrictions on its own conduct and discretion, but that does not mean that such rules are not in the public interest.

With respect to the integrity of the science used for regulatory decision making, a key issue is how to ensure that science is independent, objective, and stateof-the-art, and meets methodological and data quality requirements. In general, scientific studies should be conducted and reported in accordance with sound and generally accepted principles of sound methodology. Peer review, of course, is one way in which quality of science can be assured, and for regulatory purposes more robust peer review procedures may be desirable. ${ }^{115}$ Scientific studies that do not meet the requirements should be clearly identified as such, and they cannot be relied upon by the agency to provide positive support for a proposed rule. Another important element is how regulators best phrase their requests for scientific input, and whether and, if so, under what conditions, a regulator may deviate from opinions issued by scientific advisory bodies. If no scientific advice from an advisory body is required, the question arises how an agency best secures input from independent, qualified scientists, and what requirements apply to their reports. In light of the possible effects of the PP on science, the EU and US are well advised to pay attention to robust science protocols. In address-

115 OMB, Final Information Quality Bulletin for Peer Review, Washington DC, 2004 (issued under the Information Quality Act, this bulletin establishes government-wide guidance aimed at enhancing the practice of peer review of government science documents). Treasury and General Government Appropriations Act for Fiscal Year 2001, Pub. L. No. 106-554, 114 Stat. 2763 (2000), § 515 ("Information Quality Act"); OMB, Guidelines for Ensuring and Maximizing the Quality, Objectivity, Utility, and Integrity of Information Disseminated by Federal Agencies, 67 FR 8452, 22 February 2002; Office of Management and Budget ("OMB"), Administrator, Office of Information and Regulatory Affairs ("OIRA"), Memorandum, Information Quality Guidelines - Principles and Model Language, 5 September 2002; Office of Management and Budget ("OMB"), Final Information Quality Bulletin for Peer Review, 16 December 2004.

116 Administrative Conference of the United States, Recommendation 2013-3, Science in the Administrative Process (Adopted 14 June 2013). Pursuant to this recommendation, at an early stage in their decision making processes, agencies should "identify the specific policy questions that may be informed by science; describe the design of the assessments needed to characterize risks and inform policy decisions; and describe the criteria to be used in reviewing and weighing existing studies." They should explain "how they ensured rigorous review of the scientific information underlying each science-intensive regulatory project." To the extent practicable, agencies are to "make publicly available (...) references to the scientific literature, underlying data, models, and research results that it considered" and "ensure that members of the public have access to the information necessary to reproduce or assess ing these issues, the EU and US do not have to start from scratch. For example, they can build on the proposals for improving the use of science in the regulatory process set forth in ACUS Recommendation 2013$3^{116}$ and the approaches taken by federal agencies to implement the President's Memorandum on Scientific Integrity. ${ }^{117}$ In addition they can enhance further the 2002 Commission guidelines on the collection and use of expertise, which are aimed at "establishing a sound knowledge base for better policies."118

\section{Conclusions}

The current EU-US regulatory divergence steeped in non-transparency and mutual suspicion is no longer tenable in a quickly converging world. Beyond the precautionary rhetoric, it can likely be demonstrated, possibly subject to some exceptions, that the high standards both regions impose, although they diverge, ensure a high level of consumer, health, and environmental protection. In the EU, to a significant extent, the process of setting stringent standards has been driven by the PP, while in the US, general risk aversion may have been behind some of the stringent standards. Differences between EU and US regulatory standards are often not grounded in science, but rather based on subjective, idiosyncratic, political preferences, and cultural values employed often under the guise of differences in 'level of protection.'

the agency's technical or scientific conclusions." Further, agencies are to "encourage vigorous debate among agency scientists and should explore ways of incorporating the diversity of that debate in any resulting work product." ACUS Recommendation 2013-3, at pp. 4-7.

117 Consistent with the President's Memorandum for the Heads of Executive Departments and Agencies, "Scientific Integrity" (March 9, 2009), and its implementing guidance, each agency shall ensure the objectivity of any scientific and technological information and processes used to support the agency's regulatory actions." Executive Order 13563, supra at Sec. 5. See also The White House, President's Memorandum for the Heads of Executive Departments and Agencies, "Scientific Integrity" (March 9, 2009); Director of the Office of Science Technology and Policy, Memorandum for the Heads of Executive Departments and Agencies, "Scientific Integrity" (Dec. 17, 2010) (providing guidance on how to implement Administration scientific integrity policies).

118 European Commission. Communication on the Collection and Use of Expertise by the Commission: Principles and Guidelines Improving the knowledge base for better policies. COM(2002) 713 final, Brussels, 11.12.2002. ("There are three components The core principles of quality, openness and effectiveness should underpin all activities of the Commission in this domain. The set of guidelines should be used to help departments implement the principles. Finally, a series of practical questions should help departments design methods for collecting and using expert advice appropriate to the circumstances of specific cases."). 
Once this reality has been recognized, the EU should find it difficult to insist on the superiority of PP-based regulations. Cultural or socio-economic values cannot be protected by downplaying science. Indeed, the TTIP negotiations will hold up a mirror to the EU, the birthplace of the Enlightenment; hopefully, it will reflect an image of civilized nations making decisions based on evidence, not dogma. The US appears to be ready to revisit its own standards where they are unnecessarily stringent or bureaucratic. The citizens of Europe are entitled to expect the same of the EU.

To meet the promise of reduced regulatory trade barriers, EU and US political leaders intend to agree on a common transparent regulatory process, possibly including science protocols and trans-Atlantic consultation. If the limited information that has become available provides an accurate picture, they will attempt to achieve these results without engaging the PP and its paradoxical effects. Any such strategy may be doomed to fail, however, as value-laden PP-based regulations are much more resistant to change than mere overly cautious standards not supported by a deeper ideology. To render procedures for regulatory convergence effective, the PP itself needs to be subjected to risk-based and cost-benefit analysis, so that its adverse and paradoxical effects can be identified and neutralized. Of course, it is conceivable that the Obama administration has a hidden agenda, and intends to import the PP into US regulatory process by stealth, but no evidence has yet been adduced to substantiate this suspicion. If the two trading blocs

119 European Parliament Resolution 2012/2024(INL) - 15/01/2013 recommending to the Commission a Law of Administrative Procedure of the European Union. Cf. European Law Institute, Towards Restatement and Best Practices Guidelines on EU Administrative Procedural Law.

120 Karel De Gucht, "Speech - Transatlantic Trade and Investment Partnership (TTIP) - Solving the Regulatory Puzzle", Europa Press Release, SPEECH/13/801, 10 October 2013.

121 Davis Guggenheim, An Inconvenient Truth (film), <http://www.takepart.com/an-inconvenient-truth/film> (last accessed on 26 November 2013). An English court denied a request to prohibit, as 'promotion of partisan political views,' the distribution of this film to state secondary schools, subject to an appropriate guidance note being included in the information pack for the schools. Dimmock v Secretary of State for Education \& Skills [2007] EWHC 2288 (Admin) (10 October 2007)

122 Lucas Bergkamp (ed.), The European Union REACH Regulation for Chemicals: Law and Practice (Oxford: Oxford University Press, 2013), p. 414.

123 "All truth passes through three stages. First, it is ridiculed. Second it is violently opposed. Third, it is accepted as being self-evident." This quote has been attributed to Arthur Schopenhauer, but this attribution is doubtful. Jeffrey Shallit, Science, Pseudoscience, and The Three Stages of Truth (Waterloo: University of Waterloo, 2005). take the public interest of both jurisdictions as their lodestar, however, the TTIP negotiations will engage the PP and its effects on regulatory procedures. The timing for these efforts could not be better, as the EU is also working on reform and codification of its administrative procedure law. ${ }^{119}$

The US and EU need to face their key differences directly and boldly. As the debate about the PP and regulations based on it has become emotionally and ideologically charged in the EU, the TTIP may provide a more fruitful framework for debating and resolving these issues. There obviously are limits to what can be achieved in trade negotiations. Trade Commissioner De Gucht is right when he says that "[g]iven that the precautionary principle is enshrined in the Lisbon Treaty, nothing in the TTIP could possibly change that." ${ }^{\prime 20}$ Fortunately, however, as the elusive PP leaves much discretion, the Commission has ample space for agreeing to regulatory processes that are fit for the twenty first century. Once the inconvenient truth $^{\prime 121}$ that the PP cannot result in more protection, only in more regulation, ${ }^{122}$ is 'accepted as being selfevident, ${ }^{123}$ the parties can focus on the useful and desirable elements of EU regulatory procedure. The end game should be the establishment of a robust sciencebased procedure for mutual recognition of equivalent product-related standards, ${ }^{124}$ including standards that diverge in stringency without a basis in science. If the EU and US are up this challenge, both trade and risk regulation, and ultimately, the citizens of the world's two largest markets, will be the winners.

124 The prospect for mutual recognition of transatlantic regulatory decisions was extensively addressed in 2011 by the Administrative Conference of the United States (ACUS). The ACUS is "an independent federal agency dedicated to improving the administrative process through consensus-driven applied research." Administrative Conference of the United States, About Us, available at: $<$ http://www.acus.gov/about/the-conference/> (last accessed on 26 November 2013). The ACUS had been commissioned to review the extent of federal agency progress that had been made in implementing 1991 ACUS recommendations to improve the international regulatory cooperation process, and to evaluate and recommend how to overcome new regulatory cooperation challenges that have since emerged. ACUS Recommendation 91-1, Federal Agency Cooperation with Foreign Government Regulators (Adopted 13 June 1991). Administrative Conference, Recommendation 2011-6 International Regulatory Cooperation (Adopted 8 December 2011), 77 FR 2259-2260 (17 January 2012). Three 2011 ACUS recommendations are aimed at improving such cooperation with respect to chemicals regulation. Administrative Conference, Recommendation 2011-6 International Regulatory Cooperation (Adopted 8 December 2011); 77 FR 2259-2260 (17 January 2012). These recommendations became official US policy upon the issuance of Presidential Executive Order 13609, the objective of which is the "reduc[tion], eliminat[ion] or prevent[ion of] unnecessary differences in regulatory requirements in order to promote international trade." Executive Order 13609, Promoting International Regulatory Cooperation (1 May 2012), 77 FR 26413. 